\title{
Foreign Direct Investment in Brazil and China: A Comparative Study
}

\author{
$\mathrm{Bo} \mathrm{Xu}{ }^{1}$ \\ ${ }^{1}$ Department of Agricultural and Consumer Economics, University of Illinois at Urbana-Champaign, United \\ States \\ Correspondence: Bo Xu, Department of Agricultural and Consumer Economics, University of Illinois at \\ Urbana-Champaign, Urbana, Illinois 61801, United States. E-mail: xubmou@163.com
}

Received: September 30, 2013

Accepted: November 29, 2013

Online Published: December 15, 2013

doi:10.5539/ijbm.v9n1p35

URL: http://dx.doi.org/10.5539/ijbm.v9n1p35

\begin{abstract}
The history of foreign direct investment (FDI) inflows in Brazil and China was briefly reviewed. We examine from a contemporary policy perspective, trends and patterns, sector distribution, and productivity and growth in both countries. The comparative study of FDI in Brazil and China from the historical and contemporary perspective examines the importance of foreign capital in each stage of development in terms of various aspects we have proposed. This study also provides an understanding of FDI in both countries on the policy grounds. As far as growth and productivity is concerned. FDI has contributed to the economic development in both Brazil and China. However, the impact on the growth is only partial and will rely on other factors as well.
\end{abstract}

Keywords: foreign direct investment, economic development, impact, Brazil, China

\section{Introduction}

Foreign direct investment (FDI), by definition from International Monetary Fund (IMF), is "cross border investment where a resident in one economy has control or a significant degree of influence on the management of an enterprise resident in another economy." FDI has grown dramatically, exceeding the growth of world production and the growth of international trade (Dierk, Stephan \& Felicitas, 2008). Many countries try to attract FDI because they believe that the presence of FDI will benefit domestic firms (Lin, Liu \& Zhang, 2009; Blalock \& Gertler, 2008) and FDI can be an important source of technology for developing economies (Blalock \& Gertler, 2009).

FDI has been the key engine of growth for developing countries for the past decades (Thangavelu, Findlay, \& Chongvilaivan, 2010). Borenszteina, Gregorio and Lee (1998) tested the effect of FDI on economic growth and suggested that FDI is an important vehicle for the transfer of technology, contributing relatively more to growth than domestic investment. Laura, AreendamSebnemand Selin (2004) examined various links among FDI, financial markets, and economic growth, showed that FDI alone plays an ambiguous role in contributing to economic growth. The report of World Economic Forum Global Agenda Council on Global Trade FDI (2013) pointed that FDI is a powerful instrument for growth and development, its relevance is enhanced today by its role as the crucial engine of trade, via global value chains, and by the critical need to increase investment flows to boost the global economy, create jobs, and promote knowledge and productivity enhancements.

Brazil and China are recognized as two of the four dominant economies by 2050. However, China has witnessed slowdown during 2012; consequently it has experienced negative impacts on FDI. According to Ministry of Commerce of PRC, FDI in January 2013 dropped to 9.3 billion dollars, a 7.3\% slip compared with last year. It is the biggest drop since 2009. On the contrary, according to FGV, investments in Brazil will increase significantly due to the FIFA World Cup and the Olympic Games.

FDI was prohibited in China before 1979; this restriction was lifted as part of China's reform and opening-up policy. The gradual liberalization of restrictions on FDI has greatly improved the investment environment. Today China is the largest recipient of FDI among developing countries (Abraham, Konings, \& Slootmaekers, 2010). FDI net inflows increased from $0.2 \%$ in 1982 to $3.0 \%$ in 2011 as a percentage of GDP in China; however in net values FDI inflows to China has risen significantly from $\$ 57$ million in 1980 to $\$ 123$ billion in 2011, while in net values FDI inflows to Brazil $\$ 1910$ million in 1980 to $\$ 66$ billion in 2011, which were half the China's FDI net inflows. 
Why was there a significant jump in FDI inflows in China than in Brazil? How does FDI flow to Brazil and China? Which regions are benefited the most? Which industries are benefited the most? With export paradigms changes in China, how would the factors change? How would the stock market behave? What about private equity firms?

Although both identified as top emerging market countries, Brazil and China experienced significantly different FDI policies from a historical perspective. From the previous review of FDI we can see how FDI inflows in China have jumped compared with FDI inflows in Brazil. FDI policies in Brazil can be traced back to the $19^{\text {th }}$ century, whereas such policies have been only visible in China starting from 1979.

Based on the previous examination, therefore, we shall briefly review the history of FDI inflows in Brazil and China. As China has only opened up the economic policies since 1979, we shall skip the import substituting industrialization (ISI) stage and move on to the neo-liberalism era. Subsequently we will examine from a contemporary policy perspective, trends and patterns, sector distribution, and productivity and growth. Finally we will visit a special agricultural sector in both countries.

\section{History of FDI}

In the case of Brazil, after the independence of a few Latin American countries, Brazil gained a privileged position among those countries. It witnessed a growth in coffee exports with the labor frontier moving into State of Sao Paulo through immigration. From 1820 to 1850s, British-based foreign investments flow to finance and trade. During this period, Britain was mainly export-dominated and shipping and trading was dominated by foreign investors. In the second half of the $19^{\text {th }}$ century, foreign investments concentrated in railroads and later on public utilities. British-based foreign investors were the main source of foreign investment before the 1930s.

As for China, trade was based on the planned economy and bound by domestic policies. Following the visit by the United States president Nixon after 1972, policies have been shaped since then and eventually policies have opened up in 1979. Despite the open-up policies, early investments from Hong Kong and Taiwan have dominated the FDI inflows in the 1980s, most of which flowed to the five Special Economic Zone (SEZ). The majority of China's FDI comes from four SEZs: Shenzhen, Zhuhai, Shantou and Xiamen.

\section{FDI in the Neo-Liberalism Era}

In the case of Brazil, in the early 1980s, the average FDI inflow was around $\$ 1.5$ billion with several stagnations around 1983 to 1994 . Then the inflow reached $\$ 4.4$ billion in 1995 , rising dramatically to $\$ 10.8$ billion and $\$ 19.0$ billion in 1996 and 1997, respectively. The highest FDI inflows occurred around $\$ 32.8$ billion in 2000 and subsequently decreased to as low as $\$ 10.1$ billion in 2003. Baer (2008) argued that a number of factors have resulted in significant increase in the FDI inflows: the real stabilization program, the privatization process and the rapid implementation of Mercosul. The privatization was a major stimulus to the rise of FDI, in that foreign participation increased from 5\% in the early 1990 s to $35 \%$ in 1997.

As for China, the early 1980s witnessed several jumps in the FDI inflows. From 1980 to 1984, FDI inflows in China have risen from $\$ 57$ million in 1980 to $\$ 1.4$ billion in 1984 . The next big jump in the inflow occurred in 1992 to $\$ 11.0$ billion from $\$ 4.4$ billion in 1991. It further gained rallies to $\$ 27.5$ billion in 1993, $\$ 33.8$ billion in 1994 and experienced slowdown beginning 1997. The only decrease took place from $\$ 45.5$ billion in 1998 to $\$ 40.3$ billion in 1999. Since then, the uptrend continued and it finally reached $\$ 72.4$ billion from the largest increase from $\$ 60.6$ billion during the period following the initial rallies. Brandt and Thomas (2008) marked several important shifts in the FDI inflows in China. The first shift happened in 1984, in which the government granted exemptions from taxes and administration to fourteen additional municipalities known as "opened cities" or "export and technology development zones". Up until 1992, the majority sources of FDI inflows still came from Hong Kong and Taiwan.

\section{FDI from a Policy Perspective}

In the case of Brazil, Brazil has undergone its semi-colonial period after its independence. Britain gained privileged access to the market and trade. While in this period, the export was consist of primary goods like coffee, the rise of Brazilian nationalists have forced to change its foreign policies in the 1930s, thereby reducing the foreign activities during such period. Following the World War II in the 1950s, Brazil altered the export landscape and it witnessed the gradual shift of export to capital goods. The foreign exchange reserves accumulated in the war led to a series of reductions in trade restrictions. In the early $1950 \mathrm{~s}$, foreign investments in Brazil moved to the secondary sector, with a significant reduction in utilities. Baer (2008) argued that it was a result of various incentives granted to foreign capital. Beginning in the $1980 \mathrm{~s}$, the privatization of state-owned enterprises took the theme of government policies, serving simultaneously to prevent the fiscal pressures in the 
1980s. The primary reason was to sell those firms for immediate revenue gains. To an extent, the Brazilian government also attempted to solve the problems of inefficient state-owned enterprises. A bigger wave of privatization under the Collor government continued through the 1990s, with the emergence of National Privatization Program (Programa Nacional de Desestatização) in place. Fifteen state-owned enterprises were privatized as a result, with the $18 \%$ of acquisition by the Japanese company Nippon Usiminas.

ForChina, the imperialism ended in 1949 with the rise of Communist Party to found the People's Republic of China. The founding of the People's Republic of China abolished treaties to gain privileged positions by Japan. Despite a series of revolutions by the Chinese government, foreign trade was still not a large part of the nation's wealth, which only comprised of $2 \%$ of the gross national product. The government developed a five-year plan in the 1950s to expand on exports of agricultural products. Following the Cultural Revolution which resulted in the stagnation of trades, China drove a pragmatic modernization and successfully pushed up the trade to a new peak. However, prior to the "open-up" policy in 1978, Brandt et al. (2008) argued that the composition of Chinese trade still hardly connected with Chinese comparative advantage. Under the planned economy, the Ministry of Foreign Trade controlled the foreign trade corporations and designated import and export plans, thus exchange rates will not influence either imports or exports. In 1979, the Chinese government passed a new law on Joint Ventures which lifted some of the barriers on foreign debt and equity. With the further establishment of four Special Economic Zones, early appearances of foreign capital gradually emerged. Unlike the Brazil's privatization program, in the 1990s the Chinese government required multinational firms to form a joint venture with state-owned enterprises in China. Brandt et al (2008) explained such requirements as a "demand over supply", because during the period efficient state-owned enterprises in China were largely non-existent. Therefore, Rosen (1999) suggested that the foreign investors were unable to deal with complex procedures and inefficiencies of most state-owned enterprises. As a result, it caused a sudden slowdown in the foreign contracts.

\section{FDI Inflows: Trends and Patterns}

In the case of Brazil, the United States had contributed the bulk of FDI in Brazil throughout the 20th century. Prior to World War II, Baer (2008) stated that US investments were largely concentrated in public utilities, trade, finance and petroleum distribution, where public utilities took almost half of its investment.

The contribution of European investors had surpassed that of American investors with $48 \%$ of total FDI inflows in Brazil in 1996-2000, compared with 21\% from the United States. During 2001-2002, the share of the EU increased to 51\%; however, investments from the United States decreased to 18\%. In 2011, Netherlands became the largest contributor to FDI in Brazil, with the United States maintaining at $18 \%$.

As forChina, although it had not yet started the introduction of FDI since 1980, the FDI Flows had increased sharply between 1980 and 2011, whereas FDI Flows in Brazil experienced a decrease in 1990. Despite the significant difference in FDI inflows starting from 1990, FDI had approximately the same contribution to GDP. As a percentage of GDP, FDI inflows to China in 2002 were $3.4 \%$ in 2002 and $3.0 \%$ in 2011, while in Brazil, FDI inflows leveled at 3.3\% in 2002 and reached $2.9 \%$ in 2011.

Although European and American investors had begun their contributions to FDI since the 1990s, FDI inflows were still not diversified until 2011. Graham and Erika (2001) explained that dominance of Hong Kong-source FDI in fact results from investment by domestic Chinese that is "round-tripped" through Hong Kong. Almost all the foreign funds existed in the forms of joint ventures in China by 1992. The joint ventures are typically formed by local affiliates of foreign owned firms and Chinese enterprises. While China allows a $100 \%$ of Greenfield FDI in the banking sector, virtually all the investment banks in China are formed by joint ventures.

Table 1 shows the comparedinward FDI from top five sources between China and Brazil in 2011.

Table 1. Inward foreign direct investment from top five sources in 2011 (US Dollars, Millions)

\begin{tabular}{cccccc}
\hline & China & \multicolumn{5}{c}{ Brazil } \\
\hline China, Hong Kong & 856758 & $45 \%$ & Netherlands & 174507 & $25 \%$ \\
SAR & & & & & \\
Virgin Islands, British & 297792 & $16 \%$ & United States & 123973 & $18 \%$ \\
Japan & 121999 & $6 \%$ & Spain & 93360 & $13 \%$ \\
Singapore & 76386 & $4 \%$ & France & 35824 & $5 \%$ \\
United States & 57751 & $3 \%$ & Japan & 35384 & $5 \%$ \\
\hline
\end{tabular}

Source: International Monetary Fund. 


\section{FDI Inflows: Sectoral and Regional Distribution}

From a statistical standpoint, Laura (2003) suggested that FDI inflows have a negative effect on the primary sector, while FDI inflows impact positively on the manufacturing sector. The service sector has an undetermined impact on the FDI inflows in general. The model established by Basu and Guariglia (2007) indicated that FDI discourages the contribution of agricultural sector to the total GDP and serves as the engine for growth in the technology sector. We will examine the impacts of FDI on productivity in the following chapter.

The Pre-World War II witnessed the strong foreign participation in the public utilities sector. Half of the US investments in 1929 were devoted to the public utilities. During the ISI period, Brazil has shifted the foreign participation to the manufacturing sector with a sharp decline in public utilities. The US participation in the manufacturing sector rose to $50.6 \%$ in 1952 .

During 1986-2002, although the inward FDI stock in primary sectors in Latin American countries had increased in shares, the primary sector accounts for a small percentage of FDI inflows. Table 2 shows that about $70 \%$ of FDI inflows in Brazil came into the services sector, while this sector only employed $2 \%$ of total number of employees. For the manufacturing sector, FDI inflows increased by $40 \%$ from 2000 to 2001 and 2002 . The share of FDI inflows in manufacturing sector also rose from $15 \%$ in 2000 to $40 \%$ in 2002 . On the contrary, despite an apparent uptrend of FDI in the services sector due to privatizations of services companies. In 2001-2002, there was a sharp decrease in FDI inflows to industries like telecommunications and finance. Towards the year of 2005 , the presence of private companies in the service sector gradually increased, causing the decrease in FDI inflows to the manufacturing sector to $35.9 \%$.

As for regional variations in the FDI in Brazil, literature review is limited. Baer (2008) stated that from 1949 to 2003, although regional distribution of value added in Southeastern Brazil had been trending downwards, this region still dominated by $55.4 \%$ of the total value added, largely from manufacturing sector, which was $59.1 \%$ of value added in the industry. However, Southern Brazil showed an upward trend in agricultural contribution and exceeded the value added in Southeastern Brazil in 2003.

Table 2. FDI Inflows by sectoral distribution 1996-2001 (US Dollars, Millions)

\begin{tabular}{|c|c|c|c|c|c|c|c|}
\hline & Sector & 1997 & 1998 & 1999 & 2000 & 2001 & 2002 \\
\hline \multirow[t]{3}{*}{ Brazil } & Primary & 456 & 142 & 423 & 649 & 1494 & 638 \\
\hline & Secondary & 2037 & 2766 & 7002 & 5087 & 7001 & 7555 \\
\hline & Tertiary & 12818 & 20362 & 20147 & 24139 & 12547 & 10585 \\
\hline \multirow[t]{3}{*}{ China } & Primary & 156796 & 120184 & 126729 & 125922 & 170975 & 160870 \\
\hline & Secondary & 2811983 & 2558238 & 2260334 & 2584417 & 3090737 & 3679998 \\
\hline & Tertiary & 1399314 & 1753239 & 1569529 & 1215865 & 1320931 & 1301316 \\
\hline
\end{tabular}

Source: Central Bank of Brazil, China Statistical Yearbook.

a: Computations for Primary and Tertiary sectors in China are done by the author.

For China, we will directly come to the 1997-2002 period as the National Bureau of Statistics of China only published statistical yearbook after 1996.The compared FDI Inflows by sectoraldistribution 1996-2001 between China and Brazil were shown in Table 2. As opposed to Brazil, FDI inflows to the manufacturing sector dominated the share of FDI around that period. Averaging from 1987 to 2007, FDI inflows to the manufacturing sector accounts for $58 \%$ of the total FDI inflows. Yuyu (2009) asserted that only in the coastal region, the service sector has a decent development pace, while the service sector leads to the most sectoral inequality. Yunyun (2010) discovered that the reasons for the dominance of manufacturing sector on the total FDI inflows are high population-to-natural resource ratio and underdeveloped software and financial industry. The earliest appearance of FDI by Hong Kong and Taiwan investors was largely a result of China's cheap labor. European and North American investors joined subsequently for the same purpose. The whole landscape has not changed since then. As a result there was an overwhelming presence in the manufacturing sector.

As far as the region is concerned, literatures have slightly different definitions of FDI-dominated regions (Lian \& Haiying, 2010). However, China's preferential policies towards coastal provinces are always in place. $87 \%$ of FDI inflows to China came from Guangdong, Beijing, Fujian, Shanghai, Liaoning, Jiangsu, Shandong and Hainan by the end of 1991. Since 1992, the Chinese government has expanded the economic zones along the Yangtze River and border economic cooperation zones. In calculating regional inequalities, Yuyu (2009) 
identified four regions for the differences in FDI distribution. The top regions (tier 1) include Beijing, Tianjin, Shanghai, Hebei, Shandong, Jiangsu, Zhejiang, Fujian, Guangdong and Hainan. The first three provinces are metropolises and the latter ones are coastal provinces. Kang, Xiangyong and Xian (2008) based their research on pure geographic distribution where they identify traditional eastern China as FDI-dominated regions and Central and Western China as non-FDI-dominated regions.

While by the end of 1991, 41\% of FDI contributions came from Guangdong Province, $11 \%$ came from Beijing and 9\% came from Fujian Province, the regional variations have become less apparent between 1991 and 2011. According to Statistics Bureau of Guangdong Province, foreign investment in actual use accounts for $21.1 \%$ of total foreign investment in China. The data also shows the regional disparity, with $87.5 \%$ of contracted foreign investment and $91.4 \%$ of foreign investment in actual use concentrated in Pearl River delta region. In an effort to correct for regional variation in regards to foreign investments, Chinese policymakers have successfully reduced the contribution of regionally preferential policies from $24 \%$ in 1989 to $13 \%$ in 2005 (Kang et al., 2008).

Table 3. Foreign equity ownership indexes 2010

\begin{tabular}{lcc}
\hline \multicolumn{1}{c}{ Sector } & China & Brazil \\
\hline Primary & 99.75 & 100.0 \\
Secondary (Lightmanufacturing only) & 75.0 & 100.0 \\
Tertiary & 62.66 & 81.0 \\
TelecommunicationsElectricity & 49.0 & 100.0 \\
Power distribution \& transmissionTransport & 49.0 & 100.0 \\
Air transportation & 49.0 & 20.0 \\
Media & 0.0 & 30.0 \\
Healthcare & 70.0 & 0.0 \\
\hline
\end{tabular}

Source: The World Bank Group.

a: scaled from $0-100$, where 0 means no foreign equity ownership allowed and 100 means full foreign equity ownership.

As indicated in Table 3, foreign equity ownership inBrazil in primary and secondarysector are about $100 \%$, while China has less foreign equity ownership than Brazil in primary, secondary and tertiarysector.

\section{FDI Inflows: Productivity and Growth}

Most literatures elaborate on how FDI has driven the productivity and economic development positive (Laura, Areendam, Sebnem \& Selin, 2010). However, there were several stages in both Brazil and China's economic development which essentially discouraged foreign participation and as a result did not impede the development progress.

In the 1990s and 2000s, the service value added rose sharply in Brazil, with declines in industrial value added and manufacturing value added, as shown in Table 4. The service sector in Brazil took the most shares of FDI inflows in the 1990s, while the growth in manufacturing value added was limited. Considering the privatization process undertaken in Brazil during that period, we may find it hard to explain the rationales of foreign investors. However, if we trace back to the fundamentals that led to the massive privatization, the answer will be clearer: the low rate of economic development. The fiscal pressure for Brazil in the 1980s and 1990s drove the currency to depreciate, thereby lowering the confidence of foreign investors. A cycle, therefore, was formed in that low FDI resulted in, although not necessarily, a decrease in GDP and vice versa. Seabra and Lisandra (2005) tested the causality between FDI and profit outflows to conclude that FDI has a unidirectional causality from FDI to profit outflows for the Brazilian economy. Therefore, it can be better explained that the depreciation of the currency led to decrease in FDI and thus lower the value added as a whole. 
Table 4. Development indicators of Brazil

\begin{tabular}{lccc}
\hline & $1981-1990$ & $1991-2000$ & $2001-2010$ \\
\hline GDP growth (annual \%) & 1.6 & 2.4 & 3.6 \\
GNI per capita, PPP (current international \$) & 4350 & 6007 & 8715 \\
FDI, net inflows (\% of GDP) & 0.60 & 1.96 & 2.62 \\
Industrial, value added (\% of GDP) & 44.0 & 31.1 & 28.1 \\
Manufacturing, value added (\% of GDP) & 32.6 & 20.0 & 17.3 \\
Service, value added (\% of GDP) & 45.8 & 62.5 & 65.9 \\
\hline
\end{tabular}

Source: The World Bank Group.

In the case of China, Xiaolan (2004) adopted Myint's 'vent-for-surplus' theory as a solid basis for the exports in China. The state-owned enterprises accounted for the majority of non-agricultural employment until 1992; however that was more in the forms of disguised employment with a strong presence of diminishing marginal product of the labor. Prior to the reform in China, little surplus values can be extracted from the labor; therefore early forms of foreign investments were more of exploitation in nature. Analysis by Ramasamy and Matthew (2010) revealed an elastic relationship between wages and FDI inflow in China between 1988 and 2007, although it appears subtler for coastal provinces. They further investigate that FDI has a positive impact on productivity. Although unspecified, such effects are largely applied to the manufacturing sector.

Based on the review of regional variations in FDI in China, the inequalities have become less apparent. However, dual model still exist in China in which FDI dominated regions contribute a much higher share to the economic growth than the non-FDI dominated regions do. Whalley and Xian (2006) pointed out that the share of foreign invested enterprises (FIE) reached $20 \%$ in the whole economy and contributed over $40 \%$ to the economic development in China. Ping, Chen, and Xiaojin (2010) adopt a two-sector model by Feder to conclude a important role by foreign investments in the economic growth of China and further foreign-funded sector has accelerated the growth of domestic-funded sector in terms of development.

As indicated in Table 5, in the 1990s, FDI as a percentage of GDP peaked at an average of $4.14 \%$, with contribution to capital formation at $17 \%$ in 1994 with subsequent decline to $7 \%$ in 2003 . Brandt et al (2008) argued that Chinese consumers have benefited from price declines with an increase in quality and China has changed the pattern of industrial production to leverage the comparative advantage.

As the former members in Central Committee of the Communist Party of China stepped down, there is likely an adjustment in foreign policy. Although regional disparity seems apparent, Mi and Yum (2011) argued that the spillover effect of FDI exists on the premises that the region has strong absorptive abilities. Kelly, Daly and Maria (2012) stated that foreign investment in China typically flows from low tech to high tech manufacturing sector. Mi et al. (2011) suggested that FDI will be a larger part of capital in sectors that "are labor intensive and export oriented". They also point out that FDI is usually discouraged in industries in which state owned enterprises dominate.

Table 5. Development indicators of China

\begin{tabular}{llll}
\hline & $1981-1990$ & $1991-2000$ & $2001-2010$ \\
\hline GDP growth (annual \%) & 9.4 & 10.3 & 10.5 \\
GNI per capita, PPP (current international \$) & 533 & 1578 & 4718 \\
FDI, net inflows (\% of GDP) & 0.67 & 4.14 & 3.66 \\
Industrial, value added (\% of GDP) & 43.6 & 45.9 & 46.5 \\
Manufacturing, value added (\% of GDP) & 35.3 & 32.9 & 32.1 \\
Service, value added (\% of GDP) & 27.3 & 34.9 & 41.5 \\
\hline
\end{tabular}

Source: The World Bank Group.

\section{Conclusion}

This comparative study of FDI in Brazil and China from the historical and contemporary perspective examines the importance of foreign capital in each stage of development in terms of various aspects we have proposed. This study also provides an understanding of FDI in both countries on the policy grounds.

From a historical perspective, we can see that while Brazil has begun the early trading and consolidated the 
export-dominated position, China has not yet started its openness to foreign investors since 1979. During the neo-liberalism era, both countries have experienced sharp rise in FDI; however Brazil stimulated the foreign engagement through the privatization process while China granted exemptions to taxes and administrative procedures to increase FDI in four key regions.

For trends and patterns, despite a large share of US investment before and after World War II, the largest share of FDI has been replaced by the investors from Netherland. In the case of China, Hong Kong and Taiwan-based investors have dominated the share of China since the inception of FDI. In a way, however, some of those sources may be redirected back to mainland China.

The biggest distinction occurred in the distribution of FDI in both countries. Although Brazil and China have showed the domination in service sector and manufacturing sector, FDI in Brazil does not demonstrate a strong regional disparity. The regional inequality of FDI mainly has arisen from the policy environments since the beginning of the FDI period, although the regional disparity has been less apparent as a result of the changing political economy in China.

As far as growth and productivity is concerned, FDI has contributed to the economic development in both Brazil and China. However, the impact on the growth is only partial and will rely on other factors as well.

\section{References}

Abraham, F., Konings, J., \& Slootmaekers, V. (2010). FDI spillovers in the Chinese manufacturing sector. The Economics of Transition, 18(1), 143-182.

Baer, W. (2008). The Brazilian Economy: Growth and Development (6th ed.). Lynne Rienner Publishers.

Basu, P., \& Guariglia, A. (2007). Foreign direct investment, inequality, and growth. Journal of Macroeconomics, 29(4), 824-839. http://dx.doi.org/10.1016/j.jmacro.2006.02.004

Blalock, G., \& Gertler, P. J. (2008). Welfare gains from foreign direct investment through technology transfer to local suppliers. Journal of International Economics, 74(2), 402-421. http://dx.doi.org/10.1016/j.jinteco.2007.05.011

Blalock, G., \& Gertler, P. J. (2009). How firm capabilities affect who benefits from foreign technology. Journal of Development Economics, 90(2), 192-199. http://dx.doi.org/10.1016/j.jdeveco.2008.11.011

Brandt L., \& Thomas, G. R. (2008). China's Great Economic Transformation (1st ed.). Cambridge University Press.

Dierk H., Stephan, K., \& Felicitas N. L. D. (2008). In search of FDI-led growth in developing countries: The way forward. Economic Modelling, 25(5), 793-810. http://dx.doi.org/10.1016/j.econmod.2007.11.005

Borenszteina, E., De Gregorio, J., \& Lee, J. W. (1998). How does foreign direct investment affect economic growth? Journal of International Economics, 45,115-135.

Global Agenda Council on Global Trade and FDI. (2013). Foreign Direct Investment as a Key Driver for Trade, Growth and Prosperity: The Case for a Multilateral Agreement on Investment.

Graham, M. E., \& Erika, W. (2001). Foreign Direct Investment in China: Effects on Growth and Economic Performance. Achieving High Growth: Experience of Transitional Economies in East Asia. Oxford University Press.

Kang, Y., Xiangyong, T., \& Xian, X. (2008). Have China's FDI Policy Changes Been Successfully in Reducing Its FDI Regional Disparity? Journal of World Trade, 42(4), 641-652.

Kelly, L., Daly, K., \& Maria, E. V. (2012). Regional Determinants of Foreign Direct Investment in Manufacturing Industry. International Journal of Economics and Finance, 4(12), 178-192. http://dx.doi.org/10.5539/ijef.v4n12p178

Laura, A. (2003). Foreign Direct Investment and Growth: Does the Sector Matter? Harvard Business School.

Laura, A., Areendam, C., Sebnem, K. O., \& Selin, S. (2004). FDI and economic growth: the role of local financial markets. Journal of International Economics, 64, 89-112.

Laura, A., Areendam, C., Sebnem, K. O., \& Selin, S. (2010). Does Foreign Direct Investment Promote Economic Growth? Exploring the Role of Financial Markets on Linkages. Journal of Development Economics, 91(2), 242-256. http://dx.doi.org/10.1016/j.jdeveco.2009.09.004

Lian, L., \& Haiying, M. (2010). Revaluation of FDI on the Economy Development of China-Is It an Entirely Unalloyed Benefit? International Journal of Business and Management, 5(10), 184-190. 
Lin, P., Liu, Z., \& Zhang, Y. (2009). Do Chinese domestic firms benefit from FDI inflow? Evidence of horizontal and vertical spillovers. China Economic Review, 20(4), 677-691. http://dx.doi.org/10.1016/j.chieco.2009.05.010

Mi, L., \& Yum, K. K. (2011). Sectoral Location of FDI in China. The World Economy: Blackwell Publishing.

Ping, Y., Chen, K. C., \& Xiaojin, S. (2010). Foreign Direct Investment and Economic Growth in China: Evidence from a Two-Sector Model. Journal of Financial Management and Analysis, 23(1), 1-9.

Ramasamy, B., \& Matthew, Y. (2010). A causality analysis of the FDI-wage-productivity nexus in China. Journal of Chinese Economic and Foreign Trade Studies, 3(1), 5-23. http://dx.doi.org/10.1108/17544401011016654

Rosen, \& Daniel, H. (1999). Behind the Open Door: Foreign Enterprises in the Chinese Marketplace. Washington, DC: Peterson Institute for International Economics.

Seabra, F., \& Lisandra, F. (2005). Foreign direct investment and profit outflows: a causality analysis for the Brazilian economy. Economics Bulletin, 6(1), 1-15.

Thangavelu, S. M., Findlay, C., \& Chongvilaivan, A. (2010). FDI, Financial Constraints, and Productivity: Firm Level Study in Vietnam. In Findlay, C., F. Parulian \& J. Corbett (Eds.), Linkages between Real and Financial Aspects of Economic Integration in East Asia (pp. 316-343). ERIA Research Project Report 2009-1, Jakarta: ERIA.

Whalley, J., \& Xian, X. (2006). China's FDI and non-FDI economies and the sustainability of future high Chinese growth. Working Paper No. 12249. National Bureau of Economic Research.

Xiaolan, F. (2004). Exports, FDI, growth of small rural enterprises and employment in china.ESRC Centre for Business Research, University of Cambridge. Working Paper No. 286.

Yunyun, D. (2010). FDI in BRICs: A Sector Level Analysis. International Journal of Business and Management, $5(1), 46-52$.

Yuyu, W. (2009). Three Essays on China's Economic Growth and Inequality-the Role of FDI, Trade and Foreign Capital. Doctoral Dissertation for University of California Santa Cruz.

\section{Copyrights}

Copyright for this article is retained by the author(s), with first publication rights granted to the journal.

This is an open-access article distributed under the terms and conditions of the Creative Commons Attribution license (http://creativecommons.org/licenses/by/3.0/). 